\title{
Carisoprodol (Somadril) Induced Histological and Histochemical Changes in Renal Cortex of Pregnant Rats and Their Fetuses
}

\author{
Original \\ Hemmat Mansour Abdelhafez $z^{(1)}$ and Mervat Ahmed Abd Rabou (2) \\ Article \\ ${ }^{1}$ Zoology Department, Faculty of Science, AL-Azhar University, Egypt \\ ${ }^{2}$ Biology Department, College of Science, Jouf University, P.O. Box: 2014, Sakaka, \\ Saudi Arabia
}

\begin{abstract}
Background: Carisoprodol is a generally prescribed skeletal muscle relaxant whose primary active metabolite is meprobamate, a substance with well-established abuse potential similar to that of benzodiazepines. A number of reports showed that carisoprodol has been abused for its anodyne and relaxant effects.

Aim: The diversion and misuse of carisoprodol and its adverse health effects appeared to be dramatically increased over the last several years. This study aimed to detect the histological and histochemical changes in the cortex of renal tissue of pregnant rats and their fetuses after treatment with carisoprodol.

Materials and Methods: Thirty pregnant female rats were randomly categorized into three groups (ten pregnant female rats in each group). The first was administered oral doses of distilled water and served as control. The other two groups were administered oral doses of carisoprodol (Somadril compound) in the distilled water equivalent to $10.8 \mathrm{and} 21.6 \mathrm{mg} / 100 \mathrm{~g}$ body weight/day respectively for 15 days from the $6^{\text {th }}$ day to the $20^{\text {th }}$ day of gestation.

Results: Maternal and fetal renal cortex tissue of both treated groups showed lots of degenerative changes post-treatment with carisoprodol. The severity of these changes was more obvious in fetal cortex of renal tissue of both groups this was accompanied with numerous histochemical changes.

Conclusion: Treatment of pregnant rats with carisoprodol led to numerous dystrophic changes in the maternal and fetal renal cortex tissue. These findings provide evidence to support current recommendations to avoid the use of carisoprodol in pregnant rats except if the potential benefit justifies the risk to the fetuses.
\end{abstract}

Received: 06 October 2019, Accepted: 13 October 2019

Key Words: Carisoprodol, fetuses, histopathology, kidney, pregnant rats.

Corresponding Author: Hemmat Mansour Abdelhafez, PhD, Department of Zoology Faculty of Science AL- Azhar University, Cairo, Egypt, Tel.: +201229966891, E-mail: dr.hematmansour@yahoo.com

ISSN: 1110-0559, Vol. 43, No.3

\section{INTRODUCTION}

Skeletal muscle relaxant (SMRs) is a set of antispasmodic factors directed to supply relief of worry linked with severe aching musculoskeletal cases ${ }^{[1]}$. It is also used off-brand for several pain cases, such as stress headache and fibromyalgia ${ }^{[2]}$. However, SMRs have limited confirmed efficacy and their side effect profile is wide. Carisoprodol is a centrally skeletal muscle relaxant, structurally and pharmacologically ${ }^{[3]}$. In the 1950, carisoprodol was introduced for comforting of back ache and muscle convulsion. It has weak anticholinergic, antipyretic and painkiller properties ${ }^{[4]}$. Subsequent ingestion of large dose of carisoprodol, death is credited to the central nervous system (CNS) depression with respiratory failing. Death of a 4 year old child has caused by ingestion of $3.5 \mathrm{~g}$ of carisoprodol $\mathrm{l}^{[5]}$. Seizures and coma continually for $33 \mathrm{~h}$ followed ingestion of carisoprodol up to $14.7 \mathrm{~g}$ in an adult ${ }^{[6]}$, whereas ingestion of $9.45 \mathrm{~g}$ has caused milder CNS effects ${ }^{[4]}$. The accurate mechanism by which carisoprodol acts is not fully unstated. However, the action of carisoprodol is believed to result from its central nervous system calming effects rather than its role as a muscle skeletal relaxant ${ }^{[7]}$. Chan ${ }^{[8]}$ reported that carisoprodol can alter pain perception by prevent interneuronal action in the descending reticular development and spinal cord in the animal. The same author added that some brands of carisoprodol are Soma, Vanadom, Carisoma and Somadril; most of carisoprodol is metabolized and only a trace amount is secreted without change. The same author also added that carisoprodol is metabolized into three main metabolites by hepatic biotransformation: hydroxycarisoprodol,hydroxy meprobamate and meprobamate which were suggested in the animal studies. The side effects and possible abuse of carisoprodol may be due to changing it to meprobamate or may be due to carisoprodol alone which is a major component in reliance and toxicity ${ }^{[8,9]}$. Carisoprodol has a great ability to change due to its aptitude to potentiate the effects of other illegal drugs ${ }^{[10]}$. High dosage of carisoprodol led to symptoms of tolerance, dependence and withdrawal in humans ${ }^{[11]}$. Drug Enforcement Administration (DEA $)^{[12]}$ showed that carisoprodol abuse has expanded in the last decade in the United States. DEA added that animal studies 
managed under the directive of the National Institute on Drug Abuse (NIDA) demonstrated that particular effects of carisoprodol may be like to other central nervous system drugs such as meprobamate, chlordiazepoxide and pentobarbital; the beginning of action of carisoprodol is rapid and remains 4 to 6 hours; it is metabolized in the liver and secreted through the renal. Metabolic path of carisoprodol includes its alteration to meprobamate, a drug with substantial barbiturate-like biological actions ${ }^{[11,12]}$. Adverse reactions of carisoprodol included the central nervous system related effects such as dizziness, vertigo, drowsiness, tremor, ataxia, agitation, headache, irritability, depressive reactions, syncope and insomnia; carisoprodol may also harmfully affect on cardiovascular (postural hypotension, tachycardia and facial flushing), gastrointestinal (vomiting, nausea, hiccup and epigastric distress);it may cause idiosyncratic indications including transient quadriplegia, extreme weakness, difficulty in speech, double vision, temporary loss of vision, dilated pupils, euphoria, agitation, confusion and disorientation and overdose of carisoprodol may led to coma stupor, respiratory depression, jolt and death ${ }^{[11,12]}$. In liver and renal, carisoprodol is broken down so these organs seize the most stress as a result of its misuse ${ }^{[13]}$.

No obtainable studies were found which concerning the tissue changes in mammals post Somadril treatment. The present work designed to detect the influence of carisoprodol drug on rat's renal cortex of mothers and fetuses.

\section{MATERIALS AND METHODS}

\section{Carisoprodol Drug}

Carisoprodol drug (Somadril compound) was acquired by way of pills of a grouping product having $200 \mathrm{mg}$ carisoprodol, paracetamol $160 \mathrm{mg}$ and $32 \mathrm{mg}$ caffeine, this group was got from Mina Pharm for Pharmaceuticals and Chemical Industries, Cairo. The dose for rats were deliberated by method of Paget and Barnes ${ }^{[14]}$.

\section{Experimental animals}

Thirty female of Albino Rattus norvegicus and 20 male, 150-200 g body weight were used. Rats nourished on normal food and certain vegetables. The experiment was performed on July and August 2016 and the approval was got from ethics committee of Faculty of Science, Al-Azhar University, Egypt.

\section{Induction of pregnancy}

Female rats were mated with male $(2: 1)$ overnight. The vaginal smears were got to examine occurrence of spermatozoa. Presence of spermatozoa or vaginal plug in the vagina was considered day zero of gestation.

\section{The experimental design}

Pregnant Albino rats stayed and categorized into 3 sets after coupling, each set included 10 pregnant rats, control group (C), gravid rats were administered oral dose of the drug equal to $10.8 \mathrm{mg} / 100 \mathrm{~g}$ body weight from the day 6 to the day 20 of gestation (S1),gravid rats were administered oral dose of drug equal to $21.6 \mathrm{mg} / 100 \mathrm{~g}$ body weight from day 6 to day 20 of gestation (S2).

\section{Histological and histochemical studies}

Small pieces of renal from the pregnant rats and their fetuses were fixed in 10\% neutral buffered formalin and Bouin's solution, dehydrated in ascending grades of alcohol, cleared then embedded in paraffin. Paraffin sections of $5 \mu \mathrm{m}$ thickness were cut and stained with hematoxylin and eosin for general histological structure ${ }^{[15]}$, Mallory's trichorome stain ${ }^{[16]}$ for collagen fibers, mercuric bromophenol blue technique for detecting total proteins ${ }^{[17]}$, polysaccharides and DNA content were detected respectively by periodic acid Schiff and Feulgen method ${ }^{[18]}$ and Congo red technique ${ }^{[19]}$ for detecting amyloid protein.

\section{Quantitative histochemical analysis}

The optical density of histochemical stained sections in renal cortex tissue for total protein, DNA, PAS materials and amyloid- $\beta$ protein was documented by IPWIN 32 image analysis software.

\section{Statistical analysis}

Statistical analysis were achieved by using analyses of variance (ANOVA) according to the method of Snedecor and Cochran $^{[20]}$. Statistical Analysis for Social Science, version 8 was used to process and analyze the data.Student T-test was used to detect significant differences between groups. Data were offered as mean $\pm \mathrm{SD}$ and statistically significant when $P$ less than or equal 0.05 .

\section{RESULTS}

\section{Results of pregnant rats}

\section{Histological observations}

A histological pattern of the renal cortex tissue of a control pregnant rats showed normal glomeruli, Boman's space, proximal and distal convoluted tubules (Figure 1a). Renal cortex tissue of group S1 showed numerous degenerative changes included highly distorted and degenerated cells of the distal and proximal convoluted tubules which were surrounded by numerous fibrotic and hemorrhagic areas most of them lost their normal architecture, cellular detachment, thickening of arterial wall, edema between renal tubules, intertubular leukocytic infiltration and cellular debris in lumens of some renal tubules, most tubules were dilated, their cells had pyknotic nuclei, many of the glomerular tufts were lobulated or atrophied with wide urinary space and some were totally degenerated (Figure 1b-d). Renal cortex tissue of pregnant rats of group S2 showed many dystrophic changes included numerous degenerated tubules, congested and lobulated glomeruli with wide urinary space, prominent internal hemorrhagic areas. Signs of pyknosis, karyorrhexis and karyolysis were realized in nuclei of cells of the convoluted tubules and with cellular debris in the lumens of most 
tubules, cellular detachment of the tubular cells, thickened of arterial wall with narrow lumen and intertubular leukocytic infiltration (Figure1e and $\mathrm{f}$ ).

The normal distribution of collagen was demonstrated in the normal group (Figure 2a). Highly increased collagen fiber was found in renal cortex tissue of S1 group, but fibrotic and hemorrhagic areas in the cortex acquired red coloration (Figure 2b). Also, highly increased collagen fibres were demonstrated in the renal cortex tissue of group S2 (Figure 2c).

\section{Quantitative histochemical measurements}

A significant decrease in the mean value of total protein content was noted in S1 and S2 groups which reached $0.60 \pm 0.16$ and $0.56 \pm 0.16$ respectively (Figure $3 \mathrm{~b}, \mathrm{c}$ and Table 1) compared to the control group $(0.96 \pm 0.11$ in Figure $3 a)$. PAS +ve materials in the renal cortex tissue of groups S1\& S2 showed a significant decrease in the mean value which reached $0.22 \pm 0.01$ and $19 \pm 0.02$ respectively (Figure $4 \mathrm{~b}, \mathrm{c}$, Table 1) compared to the control group $(0.31 \pm 0.06$ in Figure 4a). A significant decrease in mean value of total DNA content were recorded in the groups of S1and S2 which reached $0.30 \pm 0.02$ and $0.29 \pm 0.02$ respectively (Figure $5 \mathrm{~b}, \mathrm{c}$, Table 1) compared to the control group $(0.40 \pm 0.04$ in Figure $5 a)$. A significant increase in the mean value of amyloid- $\beta$ protein content in the renal cortex tissue of groups S1 and S2 which reached $0.89 \pm 0.13$ and $1.00 \pm 0.13$ respectively (Figure $6 \mathrm{~b}, \mathrm{c}$, Table 1) compared to the control group.

\section{Histological observations}

Fetal renal cortex of the control group showed normal glomeruli, proximal and distal convoluted tubules, the latter had wide lumens (Figure 7a). Fetal renal cortex of group S1 showed highly distorted and degenerated cells of the distal and proximal convoluted tubules which were surrounded by numerous fibrotic areas, the glomeruli showed many changes such as they were atrophied, lobulated, degenerated or elongated and lost their normal architecture with numerous pyknotic nuclei (Figure 7b). Numerous dystrophic changes were observed in the fetal renal cortex of group S2.These changes included highly distorted and degenerated cells of distal and proximal convoluted tubules which lost their normal architecture and they were surrounded by numerous fibrotic areas this was accompanied by congested and degenerated glomeruli and tubular epithelial cytoplasm showed brown-colored pigment (hemosiderin deposition) (Figure 7c and d).

Normal distribution of collagen fibres were observed in the control group (Figure 8a).Highly increased collagen fibres were observed in the renal cortex of group S1 especially in the brush borders and in the basement membranes of the convoluted tubules and in Bowman's capsules (Figure 8b).Intensely stained collagen fibres was observed in the fetal renal cortex of group S2, most of the tubules and glomeruli were replaced by collagen fibres (Figure 8c).

\section{Quantitative histochemical measurements}

A significant decrease was detected in the mean value of total protein content in the fetal renal tissue in groups $\mathrm{S} 1$ and $\mathrm{S} 2$ which reached $0.41 \pm 0.02$ and $0.23 \pm 0.01$ respectively (Figure $9 \mathrm{~b}$, c, Table 2) compared to the control group $(0.46 \pm 0.03$ in Figure $9 a)$. PAS +ve materials in the fetal renal cortex tissue of groups $\mathrm{S} 1$ and S2 showed a significant decrease in the mean value which reached $0.25 \pm 0.02$ and $0.23 \pm 0.02$ respectively (Figure $10 \mathrm{~b}, \mathrm{c}$, Table 2) compared to the control group $(0.38 \pm 0.04$ in Figure10a). A significant decrease was realized in the mean value of total DNA content in groups S1 and S2 which reached $0.15 \pm 0.02$ and $0.12 \pm 0.03$ respectively (Figure $11 \mathrm{~b}$ and $\mathrm{c}$ and table 2) compared to the control group ( $0.23 \pm 0.05$ in Figure 11a). Amyloid $\beta$-protein in the fetal renal cortex tissue of groups S1 and S2 exhibited a significant increase in the mean value which reached $1.12 \pm 0.16$ and $0.85 \pm 0.11$ respectively (Figure $12 b$, c, Table 2)compared to the control group $(0.21 \pm 0.02$ in Figure $12 \mathrm{a})$. 

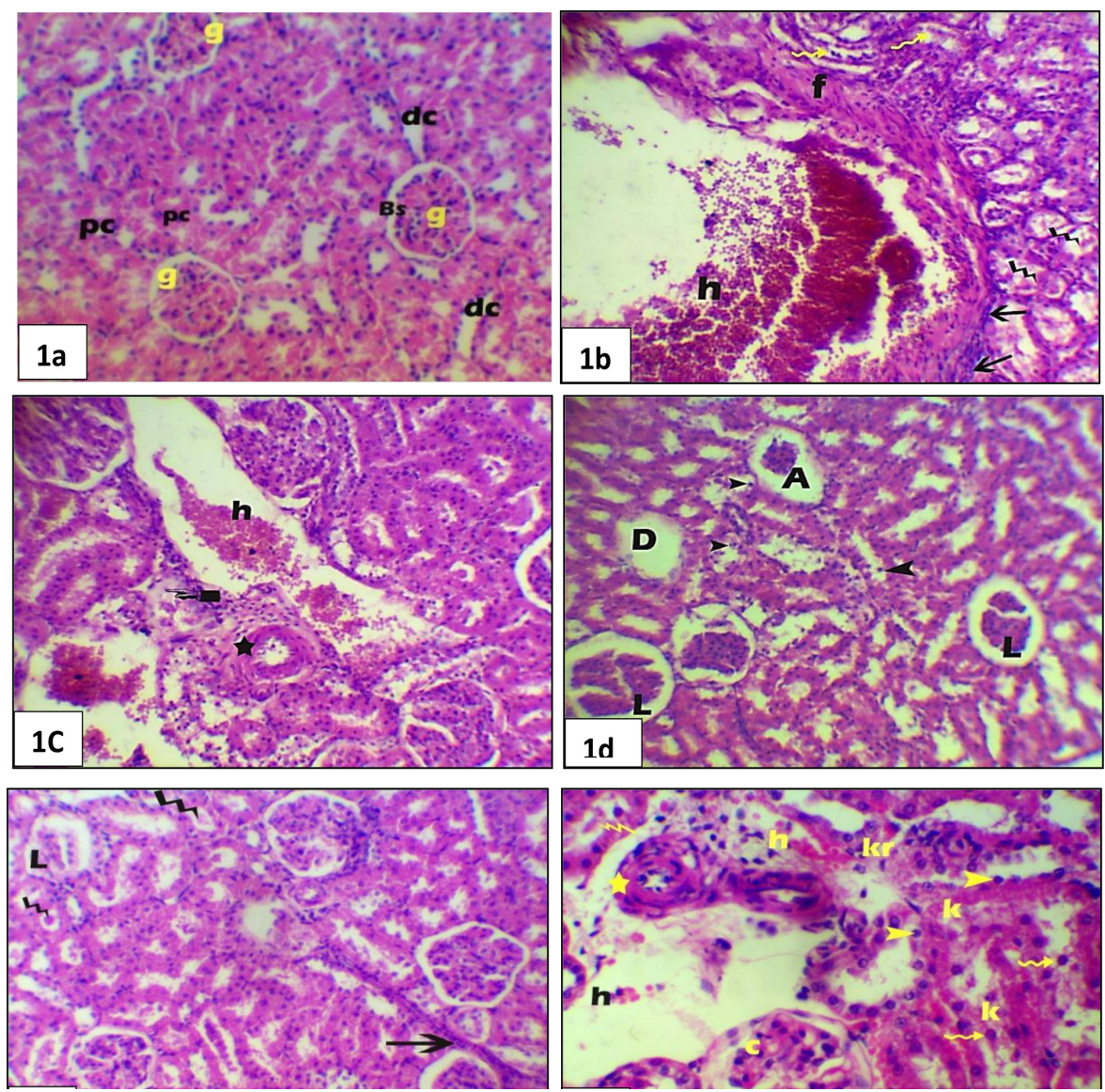

Fig.1(a-f): Photomicrographs of sections in kidney cortex tissue of pregnant rats stained with hematoxylin and eosin, (a) control group showing normal glomeruli (g),Bowman's space (Bs), proximal (pc) and distal (dc) convoluted tubules, (b-d) S1 group showing highly distorted and degenerated cells of the distal and proximal convoluted tubules which are surrounded by numerous fibrotic (f) and hemorrhagic (h) areas, cellular detachment (corrugated arrows), thickening of arterial wall (star), edema between renal tubules (hand), intertubular leukocytic infiltration $(\rightarrow)$ and cellular debris (Corrugated lines) in lumens of some renal tubules, most tubules are dilated, their cells have pyknotic nuclei $(\triangleright)$, many of the glomerular tuft are lobulated (L) or atrophied (A) with wide urinary space and some are totally degenerated (D), (e and f) S2 group showing numerous degenerated tubules, congested (C) and lobulated (L) glomeruli, pyknotic ( $\triangleright$ ), karyorrhexis (kr) and karyolitic (K) nuclei in the cells of tubules and glomeruli with cellular debris (Corrugated lines) in the lumens of most tubules, cellular detachment of the tubular cells (corrugated arrows), thickened arterial wall with narrow lumen (star) intertubular leukocytic infiltration $(\rightarrow$ ).

(Original magnification a-e X 200 \& f X 400)
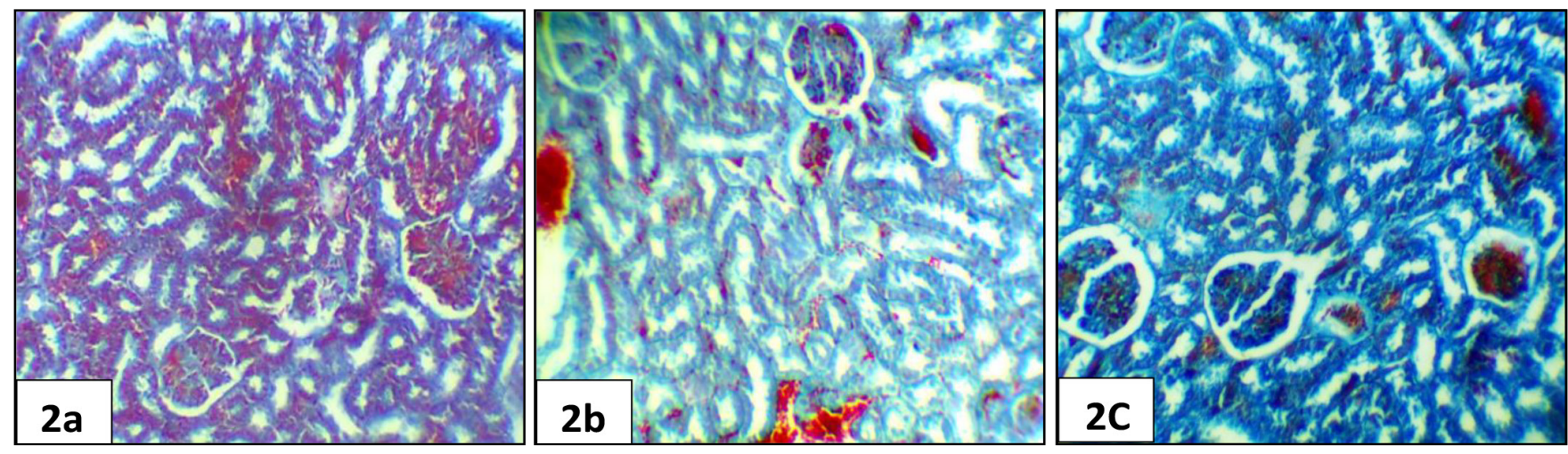

Fig.2 (a-c): Photomicrographs of sections in renal cortex tissue of pregnant rats stained with Mallory's trichrome stain showing: (a) the control group- normal distribution of collagen fibres, (b) S1 group - dense stain affinity of collagen fibres, but the fibrotic and hemorrhagic areas acquire bright red coloration,(c) S2 group -highly increased collagen fibres.

(Original magnification X 200) 

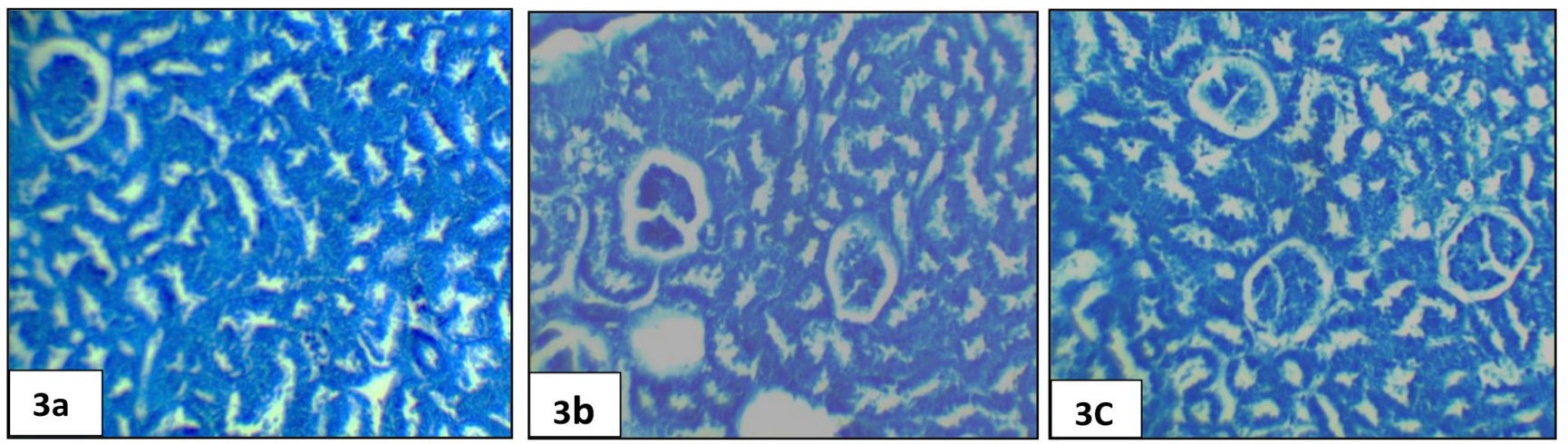

Fig.3(a-c): Photomicrographs of sections in renal cortex of the pregnant rats stained with mercuric bromophenol blue showing: (a) the control group - deeply stained glomeruli, cells of the distal and proximal convoluted tubules with less stained brush borders,(b) S1group decreased staining affinity of total protein in the glomeruli and walls of the convoluted tubules with negatively stained degenerated areas , (c) S2 group - faintly stained total protein in the convoluted tubules and glomeruli.

(Original magnification X 200)
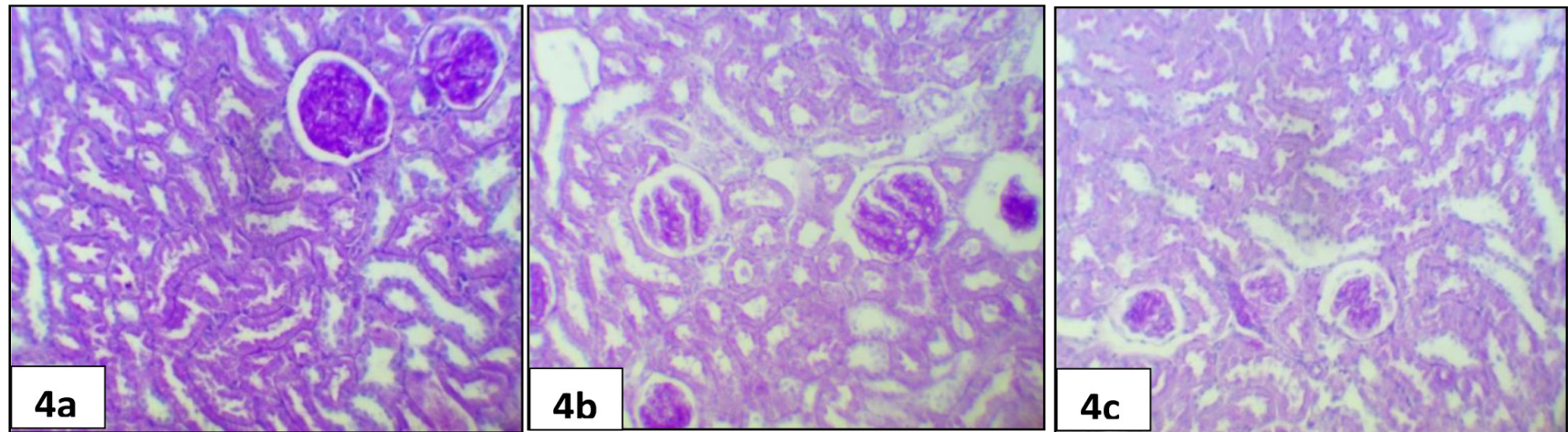

Fig.4(a-c): Photomicrographs of sections in renal cortex of the pregnant rats stained with periodic acid Schiff technique showing: (a) the control group - deeply stained glomeruli, distal convoluted tubules, Bowman's capsules and brush borders of the proximal convoluted tubules,(b) S1 group -faintly stained PAS +ve materials,(c) S2 group - highly decrease staining affinity of PAS +ve materials.
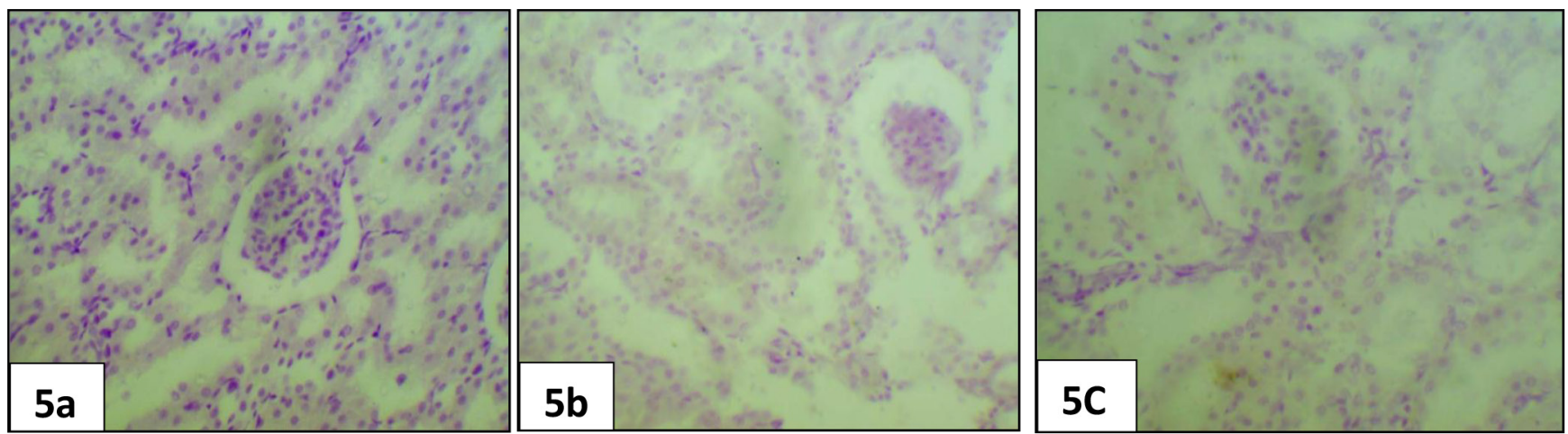

Fig.5(a-c): Photomicrographs of sections in kidney renal of the pregnant rats stained with Feulgen reaction showing :(a) the control group normal distribution of DNA in glomerular capillaries and convoluted tubules,(b) S1 group - decreased total DNA content with faintly staining affinity in the glomeruli and in the epithelial cells of the proximal and distal convoluted tubules ,(c) S2 group - highly decreased total DNA content with faintly staining affinity in the glomeruli and in the epithelial cells of proximal and distal convoluted tubules.

(Original magnificationX 400) 


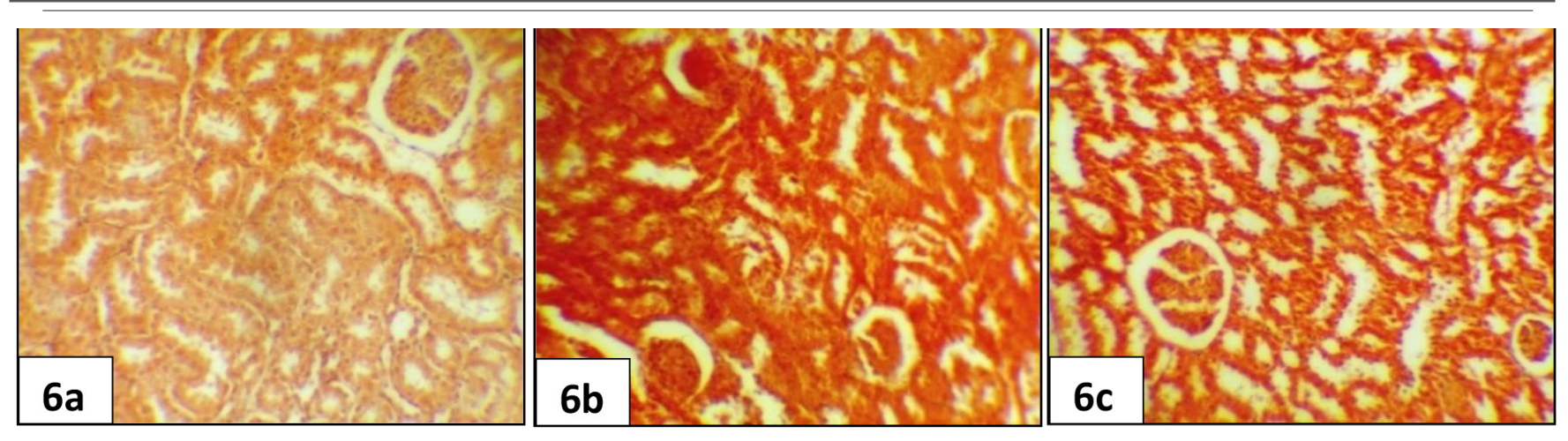

Fig.6(a-c): Photomicrographs of sections in renal cortex of the pregnant rats stained with Congo red showing : (a) the control group - faintly stained amyloid- $\beta$ protein, (b) S1 group - densely stained amyloid $\beta$-protein in the glomerular capillaries, especially in the basement membranes of some convoluted tubules and in hemorrhagic areas,(c) S2 group - densely stained amyloid $\beta$-protein.
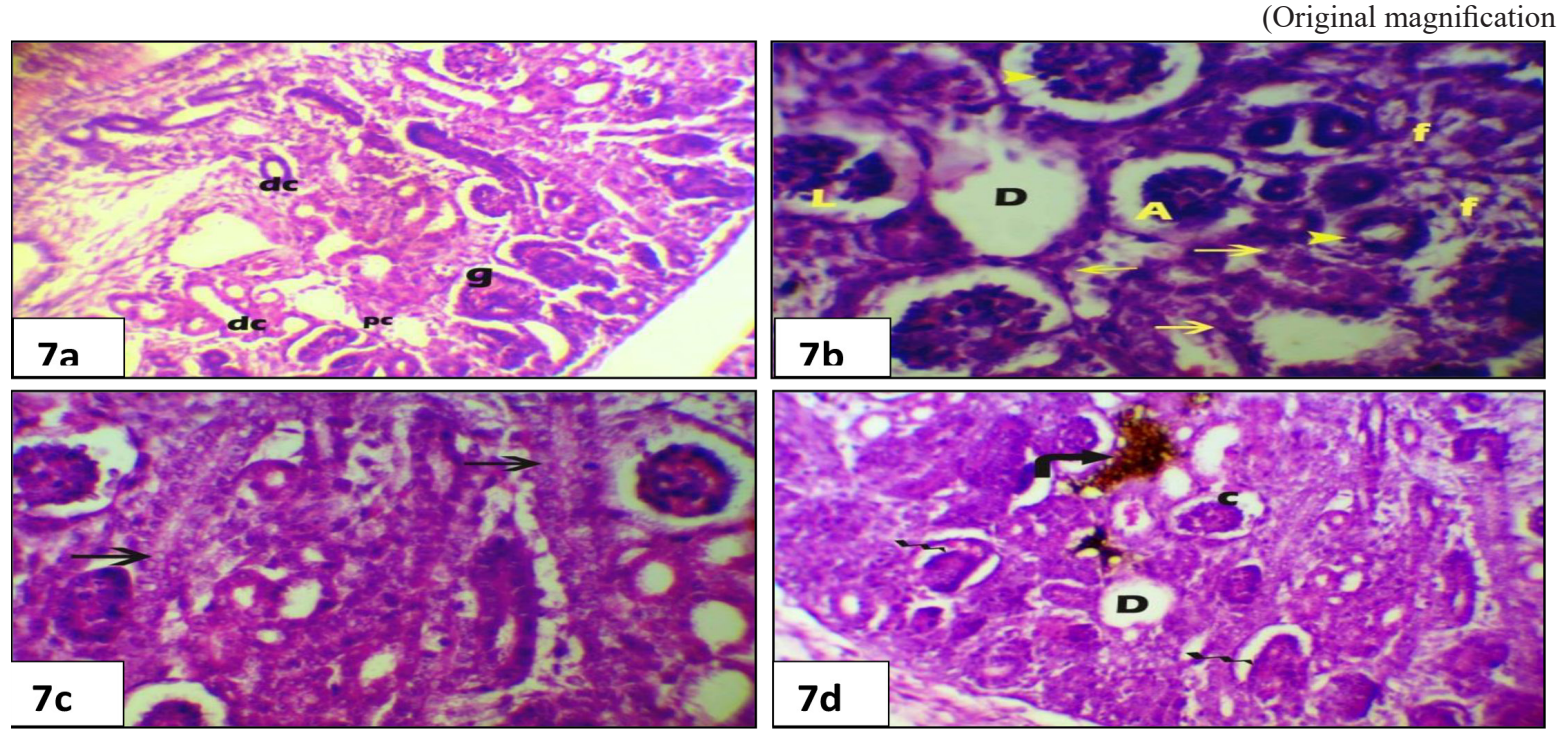

Fig.7 (a-d): Photomicrographs of sections in fetal renal cortex stained with hematoxylin and eosin,(a)control group shows normal glomeruli $(\mathrm{g})$, proximal (pc) and distal (dc) convoluted tubules the later had wide lumens,(b)S1 group shows highly distorted and degenerated cells $(\rightarrow$ ) of distal and proximal convoluted tubules which are surrounded by numerous fibrotic (f) areas, glomeruli are atrophied (A), lobulated (L), degenerated (D), with numerous pyknotic nuclei (arrow head),(c\&d) S2 group showing highly distorted and degenerated cells of the distal and proximal convoluted tubules $\rightarrow$ ) which lost their normal architecture and surrounded by numerous fibrotic areas. Glomeruli are congested (c), degenerated (D) or with abnormal shape (corrugated line). Tubular epithelial cytoplasm showing brown-colored pigment (hemosiderin deposition) (curved arrow).

(Original magnification a\&d X 200 - b \&c X 400)
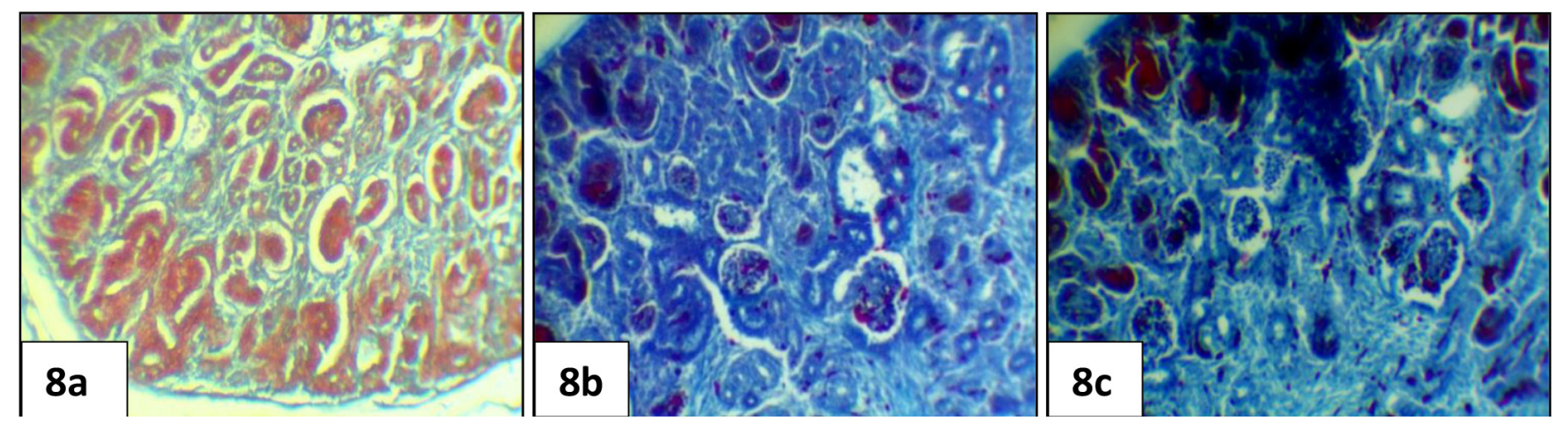

Fig.8(a-c): Photomicrographs of sections in fetal renal cortex tissue stained with Mallory's trichrome stain showing:(a) the control group collagen fibres supporting the stroma, the capsule, walls of the convoluted tubules, brush borders of the proximal convoluted tubules and Bowman's capsules, (b) S1 group - highly increased collagen fibres especially in the brush borders and in the basement membranes of the convoluted tubules and in Bowman's capsules, (c) S2 group - intensely stained collagen fibres and most of the tubules and glomeruli are replaced by collagen fibers.

(Original magnification X200) 

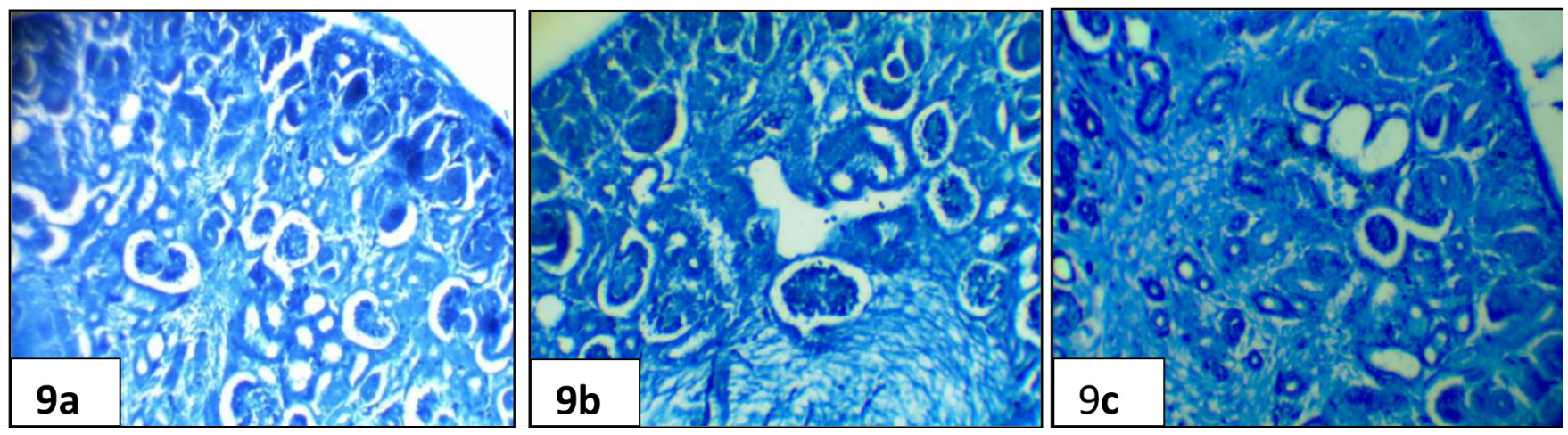

Fig.9(a-c): Photomicrographs of sections in fetal renal cortex stained with mercuric bromophenol blue showing:(a) the control group -deeply stained glomeruli and cells of the distal and proximal convoluted tubules of fetal kidney cortex ,(b) S1 group- decreased stain affinity of total protein in distal and proximal convoluted tubules and glomeruli, (c) S2 group -decreased staining affinity of total protein in the necrotic and fibrotic areas.

(Original magnification X200)
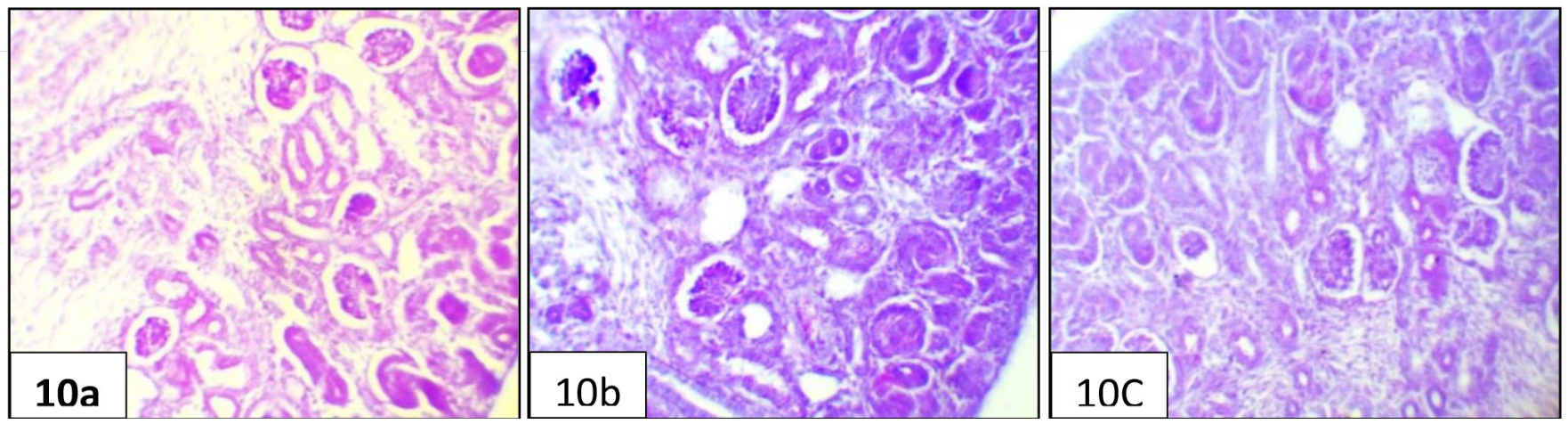

Fig.10(a-c): Photomicrographs of sections in fetal renal cortex stained with periodic acid Schiff technique showing: (a) the control group - deeply stained golmeruli, Bowman's capsules, proximal convoluted tubules, but distal convoluted tubules are less stained ,(b)S1group poorly stained polysaccharides ,(c) S2 group - faintly stained PAS +ve materials in the glomeruli and some epithelial cells of the convoluted tubules.

(Original magnification X200)
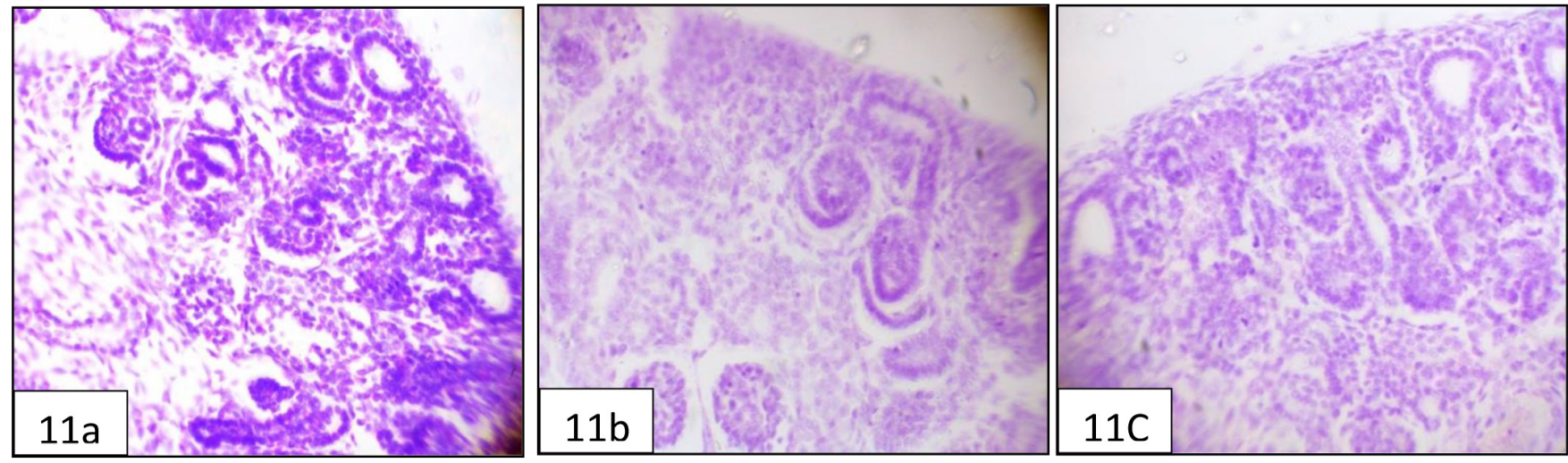

Fig.11(a-c): Photomicrographs of sections in fetal renal cortex stained with Feulgen reaction showing: (a) control group - normal distribution of DNA in glomerular capillaries and convoluted tubules, (b) S1 group - decreased total DNA content with faintly stain affinity in the glomeruli and in the epithelial cells of proximal and distal convoluted tubules, (c) S2 group - poorly to moderately stained DNA materials. (Original magnification X 400) 


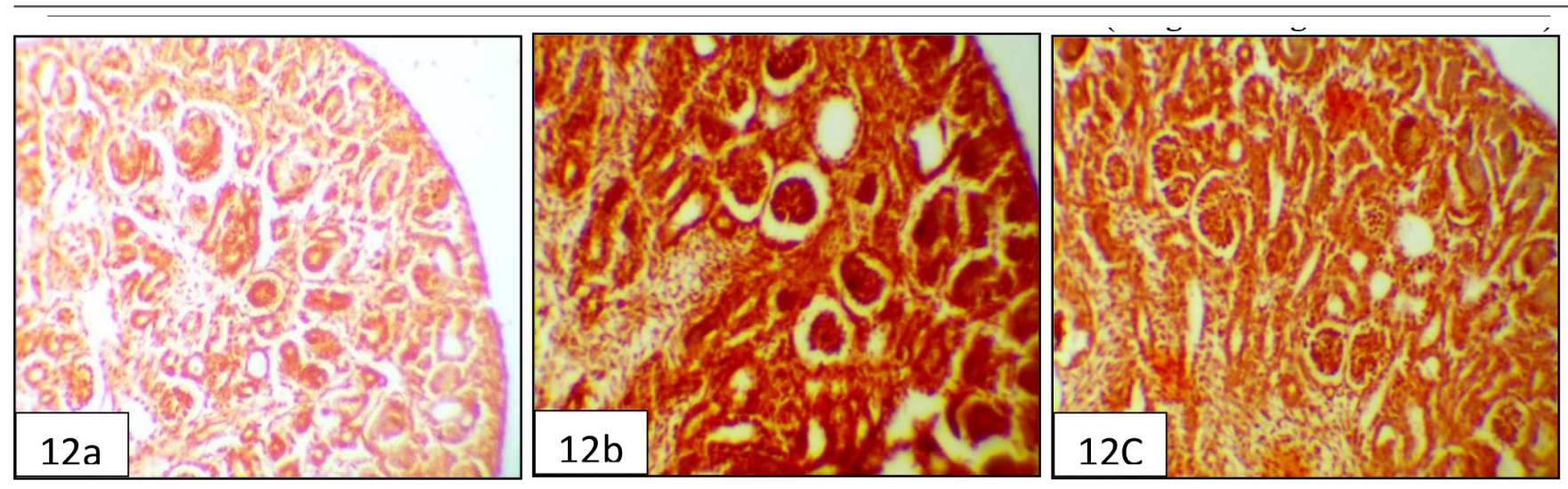

Fig.12(a-c): Photomicrographs of sections in the fetal renal cortex stained with Congo red showing: (a ) the control group - faintly stained amyloid- $\beta$ protein, (b) S1 group - densely stained amyloid $\beta$-protein in the glomerular capillaries, especially in the basement membranes of some convoluted tubules,(c) S2 group -deeply stained amyloid deposits.

(Original magnification X 200)

Table 1: Revealing mean optical density values of total protein, PAS + ve materials, DNA content and amyloid $\beta$ protein in the kidney cortex of pregnant rats

\begin{tabular}{lccc}
\hline \multicolumn{1}{c}{ Parameters } & $\begin{array}{c}\mathrm{C} \\
(\mathrm{Mean} \pm \mathrm{SD})\end{array}$ & $\begin{array}{c}\mathrm{S} 1 \mathrm{~S} \\
(\mathrm{Mean} \pm \mathrm{SD})\end{array}$ & $0.56 \pm 0.16^{*}$ \\
Total protein & $0.96 \pm 0.11$ & $0.60 \pm 0.16^{*}$ & $0.19 \pm 0.02^{*}$ \\
PAS+ve materials & $0.31 \pm 0.06$ & $0.22 \pm 0.01^{*}$ & $0.29 \pm 0.02^{*}$ \\
Total DNA conten & $0.40 \pm 0.04$ & $0.30 \pm 0.02^{*}$ & $1.00 \pm 0.13^{*}$ \\
Amyloid $-\beta$ protein & $0.26 \pm 0.03$ & $0.89 \pm 0.13^{*}$ & \\
\hline
\end{tabular}

SD means standard deviation, * Significant from the control group $(P \leq 0.05)$.

Table 2: Revealing mean optical density values of total protein, PAS + ve materials, DNA content and amyloid $\beta$ protein in fetal renal cortex

\begin{tabular}{|c|c|c|c|}
\hline \multirow[t]{2}{*}{ Groups } & \multicolumn{3}{|c|}{ Groups } \\
\hline & $\begin{array}{c}\mathrm{C} \\
(\text { Mean } \pm \mathrm{SD})\end{array}$ & $\begin{array}{c}\mathrm{S} 1 \\
(\text { Mean } \pm \mathrm{SD})\end{array}$ & $\begin{array}{c}\mathrm{S} 2 \\
(\text { Mean } \pm \mathrm{SD})\end{array}$ \\
\hline Total protein & $0.46 \pm 0.03$ & $0.41 \pm 0.02 *$ & $0.23 \pm 0.01 *$ \\
\hline PAS+ve materials & $0.38 \pm 0.04$ & $0.25 \pm 0.02 *$ & $0.23 \pm 0.02 *$ \\
\hline Total DNA content & $0.23 \pm 0.05$ & $0.15 \pm 0.02 *$ & $0.12 \pm 0.03 *$ \\
\hline Amyloid $-\beta$ protein & $0.21 \pm 0.02$ & $1.12 \pm 0.16^{*}$ & $0.85 \pm 0.11^{*}$ \\
\hline
\end{tabular}

SD means standard deviation, * Significant from the control group $(P \leq 0.05)$.

\section{DISCUSSION}

Renal is a main probable path for imbibing of risky substances occurred in the environment ${ }^{[21]}$. It was chosen in this study because it is a very vital organ for healthy life of mammals. Soma is processed to meprobamate, a schedule II drug that has been correlated with misuse, dependence and central nervous system side effects ${ }^{[22]}$. Harms of carisoprodol poses a danger of high dosage which may cause respiratory depression, hypotension, seizures and death. Carisoprodol intoxication may lead to Serotonin syndrome. Patients at huge hazards of carisoprodol effect may be due to lengthened use of it or those who use carisoprodol in blend with other injured drugs ${ }^{[23]}$.

In the present study, histopathological observation of renal cortex tissue of pregnant rats treated with carisoprodol showed many deleterious changes in the renal cortex tissue of the pregnant rats of groups $\mathrm{S} 1$ and S2 such as highly distorted and degenerated cells of the distal and proximal convoluted tubules, hemorrhagic areas, thickening of the arterial walls, edema between the renal tubules, many of the glomerular tufts were lobulated or atrophied. Signs of pyknosis ,karyorrhexis and karyolysis were realized in nuclei of cells of the convoluted tubules. Also, examination of the fetal renal cortex tissue of groups S1 and S2 showed many hurtful changes such as atrophied, lobulated, degenerated or elongated glomeruli with numerous pyknotic nuclei. Highly distorted and degenerated cells of the distal and proximal convoluted tubules were demonstrated and tubular epithelial cytoplasm showed brown-colored pigment. In vitro study established that carisoprodol owns barbiturate like properties are 
analogous other Schedule IV drugs such as barbital, meprobamate and demonstrated that extreme carisoprodol use makes toxicity and withdrawal symptoms alike to other Schedule IV drug ${ }^{[12]}$. Results of the present study are supported by results of $\mathrm{Chan}^{[8]}$ who declared that treatment with carisoprodol at doses of $400 \mathrm{mg} / \mathrm{kg}$ or greater in male rats caused a slight exacerbation of chronic nephropathy demonstrated by increased lesion rates and severities; in four males in the $1,600 \mathrm{mg} / \mathrm{kg}$ group, minimal tubule epithelial necrosis was found in the renal cortex and was proved by necrotic cells that were desquamated into lumens of the cortical tubules. The same author added that the average severity of nephropathy was minimally increased compared to the vehicle controls in males administered 200 $\mathrm{mg} / \mathrm{kg}$ or greater while, in the $800 \mathrm{mg} / \mathrm{kg}$ group of females increased nephropathy was observed. The same author stated that the renal of male rat was more susceptible to the effects of carisoprodol than the renal of female. The hazards related to carisoprodol abuse may lead to seizures and death ${ }^{[24]}$. The true mechanism of action of carisoprodol is unidentified; however, past experiment recommended that carisoprodol might act via the $\gamma$-aminobutyric acid (GABA)-ergic system ${ }^{[25]}$. The capability to reabsorb, secrete and/or renally eject carisoprodol may affect both therapeutic and pharmacokinetic results; such as rise in plasma concentrations and a reduction in renal elimination of famotidine, a histamine H2-receptor antagonist in elderly and renal impaired patients ${ }^{[26]}$. Also, reduction in creatinine clearance was detected in both elderly and renal dysfunction patients because of weakening in glomerular filtration, the ratio of famotidine clearance to creatinine clearance also declined. This was suggestive of possible decaying of renal secretory devices that may be present in both elderly and renal defective patients ${ }^{[27]}$.

Congenital defects during the first trimester of pregnancy may be occurred by carisoprodol ${ }^{[28]}$. A animal study showed that carisoprodol crosses the placenta and causes opposing effects such as decreased fetal weights, postnatal weight gain and postnatal endurance at maternal doses equivalent to 1 to 1.5 times the human dose $\mathrm{e}^{[23]}$. These results agree with our results and results of Abouel-Magd ${ }^{[29]}$ since fetal tissues maternally treated with carisoprodol were highly affected, but these results don't agree with those of Briggs et al. ${ }^{[30]}$ who stated that carisoprodol did not cause developmental injuries, but the long-term follow-up of this drug appeared later in life.

In this study, highly increased collagen fibres were detected in the renal tissue of pregnant rats of group S1 and S2; this increase was observed in the fetal renal cortex of group S1 especially in the brush borders and in the basement membranes of the convoluted tubules and in Bowman's capsules. Intensely stained collagen fibers were observed in the fetal renal cortex of group S2 compared to the control group. Hassan et al. ${ }^{[31]}$ reported that increased collagen fibres may lead to protection from toxicant substance. Increased collagen deposition may be lead to oxidative stress that stimulates the expression of genes involved in collagen biosynthesis ${ }^{[32]}$. Increased superoxide anion formation by inhibition of superoxide dismutase (antioxidant enzyme) stimulates collagen production and this indicated important role of superoxide dismutase and the generated reactive oxygen species in collagen accumulation $^{[33]}$. These results agree with those of AbouelMagd ${ }^{[29]}$ who found increased collagen fibres in the liver tissue of pregnant rats and their fetuses maternally treated with carisoprodol.

Results of the present study showed decreased staining affinity of total protein in the glomeruli and walls of the convoluted tubules of groups S1 and S2 in the renal of pregnant rats and their fetuses compared to the control group. Proteins are chiefly involved in the architecture of cells ${ }^{[34]}$. It is related to insulin regulation, glucose control, muscle building and regulation or increased metabolism ${ }^{[35]}$. The accumulation and degeneration led to reduced protein content in the altered tissues ${ }^{[36]}$. Abu Elnaga and Abd $\mathrm{Rabou}^{[37]}$ mentioned that decreased protein content due to broken cellular organoids or to reduced polyribosomes. The reduction in the protein content under the effect of many toxicants may be due to the disruption of lysosomal membranes which cause release of their hydrolytic enzymes in the cytoplasm and cause lysis and dissolution of the target material within the cytoplasm ${ }^{[38]}$.

Also, Abouel-Magd ${ }^{[29]}$ found decreased in protein content in liver tissue of pregnant rats and their fetuses treated with carisoprodol. Reduced staining affinity of total protein in the different layers of fetal esophagus maternally treated with carisoprodol was recorded by Abd Rabou ${ }^{[39]}$.

In the present study, renal cortex tissue of pregnant rats and their fetuses of S1 and S2 groups showed a significant reduction in the polysaccharides. This reduction due to the stress on organs and that lead to use great energy in attempt to balance the pressure, or may be due to release of hydrolytic enzymes from broken lysosomes under the belongings of toxic agents ${ }^{[40,41]}$. These results agree with the study of Abouel-Magd ${ }^{[29]}$ who found the reduction in contents of carbohydrate in the liver tissue of pregnant rats treated with carisoprodol.

The current results showed highly reduced DNA materials in the glomeruli and in the epithelial cells of the proximal and distal convoluted tubules of renal cortex of pregnant rats and their fetuses compared to the control. The present results agree with results of Chan ${ }^{[8]}$ who stated that carisoprodol induced chromosomal aberrations in the ovary hamster cells of cultured Chinese at the maximum concentration $(1,000$ or $1,250 \mu \mathrm{g} / \mathrm{mL})$. The reduction in total protein content and DNA may be due to the arrest of metabolism or to use them to set up the new cells or enzymes to reduce the stress and also break of lysosomal membranes under the effect of many toxicants cause releasing the marked lysis and dissolution of destination materials $^{[22]}$.

A significant increase was recorded in the amyloid protein of renal cortex of pregnant rats and their fetuses of $\mathrm{S} 1$ and S2 groups compared to the control group. Amyloids 
are insoluble fibrous proteins and they arise from at least 18 unsuitably folded forms of proteins and polypeptides, which present naturally in the body ${ }^{[43]}$. These misfolded constructions alter their good configuration such that they erroneously interact with one another or other cell components forming insoluble fibrils. They have been related to the pathology of more than 20 serious human illnesses since abnormal accretion of amyloid fibrils in organs may lead to amyloidosis and have a role in numerous neurodegenerative diseases ${ }^{[44]}$. Kadowaki et al. ${ }^{[45]}$ showed that amyloid deposition was related to mitochondrial dysfunction and caused generation of reactive oxygen species (ROS), which caused automatic cell death.

Fetal liver tissue took from mothers treated with carisoprodol showed increased amyloid protein in most liver cells, necrotic regions and blood cells ${ }^{[29]}$. Also, results of the present study are supported by results of Abd Rabou $^{[39]}$ who realized increased amyloid protein in the different layers of fetal esophagus maternally treated with carisoprodol. The histological changes that occurred in the renal cortex of both pregnant rats and their fetuses are due to carisoprodol alone because the rest of the components of Somadril as paracetamol, which is safe for pregnant women $^{[46]}$ and caffeine present in a small amount, which is ineffective ${ }^{[47]}$. Other studies are needed to assess the skeletal muscle relaxants medicines and their effect on the pregnant female and their fetuses.

\section{CONCLUSION}

According to previous observations, we can be concluded that the using carisoprodol during pregnancy caused many hazards changes in the renal cortex tissue of pregnant rats and their fetuses. Crossing of carisoprodol from placenta of gravid rats to the fetuses, that a sign to avoid administration of carisoprodol during pregnancy period.

\section{CONFLICTS OF INTEREST}

There are no conflicts of interest.

\section{REFERENCES}

1. Meda Pharmaceuticals Inc. Product information. Soma (carisoprodol) tablet. Somerset, NJ. Somerset, New Jersey 2009.

2. See S and Ginzburg R. Choosing a skeletal muscle relaxant. Amer. Fam. Phys. 2008; 78:365-70. Available on: http://www.aafp.org/afp/2008/0801/ p365.html[Accessed 1 Mar 2013].

3. American Society of Hospital Pharmacists (AHFS) Drug Information. Bethesda . 1986.

4. Reynolds JE. Martindale- the extra pharmacopeia.30th Ed., 1993 . Pharmaceutical Press, London.p:1202.

5. Adams HR, Kerzee T and Morehead CD. Carisoprodol related death in a child. J For Sci., 1975; 20(1): 200-202.
6. Brandslung I, Klitgaard NA and Kristensen O. A case of acute intoxication with carisoprodol. Symptoms and metabolism. Ugeskr Laeg., 1976;138: 281-283.

7. Olsen H, Koppang E, Alvan G and Morland J . Carisoprodol elimination in humans. Ther. Drug Monit .1994; 16: 337-340.

8. Chan PC. NTP toxicity studies of carisoprodol administered by gavage to $\mathrm{F} 344 / \mathrm{N}$ rats and $\mathrm{B} 6 \mathrm{C} 3 \mathrm{~F} 1$ mice. National Toxicology Report Series 2000. 56: $1-14$.

9. Gonzalez LA, Gatch MB, Taylor CM, Bell-Horner CL, Forster MJ and Dillon GH. Carisoprodol-mediated modulation of GABAA receptors: in vitro and in vivo studies. J. Pharmacol. Exp. Ther., 2009;329 (2): 827-837.

10. Reeves RR and Liberto V. Abuse of combinations of carisoprodol and tramadol. Southern Medical Journal, 2001; 94:512-514.

11. Bramness JG, Buajordet I and Skurtveit S. The role of pharmacoepidemiological studies in the market withdrawal of carisoprodol (Somadril $\AA$ ) in Europe. Norsk Epidemiologi 2008; 18 (2): 167-172.

12. Drug Enforcement Administration. Schedule of controlled substances: placement of carisoprodol into Schedule IV. Fed. Reg. 2011;76: 77330-77360.

13. American Society of Health System Pharmacists(AHFS). Drug Information, Bethesda 2010; p.1391.

14. Paget GE and Barnes JM. Interspecies dosage conversion scheme in evaluation of results and qantitative application in different species. In: Evaluation of Drug Activities, Laurence, D .R. and A. L. Bacharach, (Eds.).Academic Press, London and USA., 1964 pp: 160-162.

15. Suvarna SK, Layton C and Bancroft JD.Theory and practice of histological techniques. $8^{\text {th }}$ ed., Churchill Living Stone, London, 2018.

16. Kiernan JA. Histological and histochemical methods - theory and practice. $5^{\text {th }}$ ed., Scion Publishing Ltd. Banbury, UK., 2015.

17. Cook DJ, Warren PJ. Cellular pathology: an introduction to techniques and application. 3rd ed., Scion Publishing Ltd., 2015.

18. Suvarna SK, Layton C and Bancroft JD.Theory and practice of histological techniques. 7th ed., Churchill Living Stone, London, 2013.

19. Dey P. Basic and advanced laboratory techniques in histopathology and cytology. Springer Nature Singapore Pte Ltd., 2018 pp: 109-111. 
20. Snedecor WG and Cochran GW. Statistical Method. $7^{\text {th }} 1980$ Ames. Iowa. London.

21. Gholampour F, Owji SM and Javadifar TS. Chronic exposure to extremely low frequency electromagnetic field induces mild renal damages in rats. Inter. J. Zoolog Res. 2013; 7(6):393-400.

22. Spence MM, Shin P J, Lee E A and Gibbs NE. Risk of injury associated with skeletal muscle relaxant use in older adults. The Annals of Pharmacotherapy 2013;47:993-998.

23. Meda Pharmaceuticals Inc. SOMA® COMPOUND CIV. Carisoprodol and aspirin tablets, USP for Oral use. Somerset, New Jersey 2013; 08873-4120. Reference ID: 3253736.

24. Reeves RR and Parker JD. Somatic dysfunction during carisoprodol cessation: evidence for a carisoprodol withdrawal syndrome. JAOA 2003; 103: 75-80.

25. Roberge RJ, Lin E and Krenzelok EP.Flumazenil reversal of carisoprodol (Soma) intoxication. J. Emerg. Med. 2000; 18:61-64

26. Lin JH, Chremos AN, Yeh KC, Antonello $\mathrm{J}$ and Hessey GA . Effects of age and chronic renal failure on the urinary excretion kinetics of famotidine in man. European Journal of Clinical Pharmacology 1988; 34: 41-46.

27. Rowland M and Tozer TN .Clinical Pharmacokinetics and Pharmacodynamics in: Concepts and Applications, 4th Ed.,2009 Lippincott William and Wilkins, Philadelphia.

28. Medical Economics Company. Physician's Desk Reference. $50^{\text {th }}$ ed., London 1996, pp: 2674-2675.

29. Abouel-Magd, M. Maternal and fetal toxicity of carisoprodol. The Egyptian Journal of Hospital Medicine 2018; 71(1): 2322-2350.

30. Briggs G, Ambrose P, Nageotte $M$ and Padilla G. High-dose carisoprodol during pregnancy and lactate/ on. The Annals of Pharmacotherapy.2008; 42:898:901.

31. Hassan H, Ghaly E, El-Nashar A and Manggoud H. Histochemical study on some organs of rats fed rape seed and cotton seed oils. Egypt. J. Histol. 1988; 11(2): 247-252.

32. Guler G, Turkozer Z, Ozgur E, Tomruk A and Seyhan N. Protein oxidation under extremely low frequency electric field in guinea pigs. Effect of N-acetyl-Lcysteine treatment. Gen. Physiol. Biophys. 2009; 28: 47-55.

33. Lijnen P, Prihadi JS, Van-Pelt JF and Fagard RH. Modulation of reactive oxygen species and collagen synthesis by angiotensin II in cardiac fibroblasts. The Open Hypertension J. 2011; 4: 1-17.
34. Radwan MA, Essawy AE, Abdel-Meguied NE, Hamed SS and Ahmed AE. Biochemical and histochemical studies on the digestive gland of Eobania vermiculata snails treated with carbamate pesticides. Pestic. Biochem. Physiol. 2008; 90: 154-167.

35. Jeor ST and Ashley JM. Dietary strategies: issues of diet composition. In: Obesity: Impact on Cardiovascular Disease. Futura, N.Y. Publishing Co.2009, New York, pp: 233-246.

36. Al Gahtani, S. Histological and histochemical studies on the effect of two different types of magnetic field on the liver and renal of Albino rats. 2006, M.Sc. Thesis, Faculty of Science, Dammam, K.S.A.

37. Abu Elnaga NA and Abd Rabou MA. The possible protective role of bone marrow transplantation on irradiated mothers and their fetuses. Stem Cell. 2012; 3(3): 8-30.

38. Abdelmeguid NE, Chmaisse HN and Abou NZ. Silymarin ameliorates Cisplatin-induced hepatotoxicity in rats: histopathological and ultrastructural studies. Pakistan J. Biol. Sc. 2010; 13(10): 463-479.

39. Abd Rabou MA. Histological and histochemical alterations induced in rats fetal esophageal tissue intoxicated maternally with carisoprodol. The Egyptian Journal of Hospital Medicine 2019; 75 (2): 2254-2260.

40. Sakr SA and Okdah YA. Histological and histochemical alteration induced in the testicular tissue of mice intoxicated with benomyle. J. Biol. Sci. 2004; 4(4): 498-500.

41. Farrag $\mathrm{AH}$ and Shalby SE .Comparative histopathological and histochemical studies on IGR, lufenuron and profenofos insecticide albino rats. J. Appl. Sc. Res. 2007; 3(5): 377-386

42. Sakr SA and Shalaby SY. Ginger extract protects metalaxyl-induced histomorphological and histochemical alterations in testes of albino mice. $\mathrm{J}$ App. Pharm. Sci .2011; 1(10): 36-42.

43. Ramirez-Alvarado M, Merkel JS and Regan L. A systematic exploration of the influence of the protein stability on amyloid fibril formation in vitro. PNAS 2000; 97 (16): 8979-8984.

44. Pulawski W, Ghoshdastider U, Andrisano V and Filipek S. Ubiquitous amyloid. Applied Biochem Biotechnol 2012; 166 (7): 1626-1643.

45. Kadowaki H. Amyloid beta induces neuronal cell death through ROS-mediated ASK1 activation. Cell Death Differ. 2005; 12(1): 19-24.

46. Fays LD, Malderen KV, Smet KD, Sawchik J, Verlinden V, Hamdani J, Dogné J and Dan B. Use of paracetamol during pregnancy and child neurological 
development. Developmental Medicine \& Child Neurology,2015;57(8): 718-724

47. Błaszczyk-Bębenek E, Piorecka B, Kopytko M, Chadzinska Z, Jagielski P and Schlegel-Zawadzka M.
Evaluation of Caffeine Consumption among Pregnant Women from Southern Poland. Int. J. Environ. Res. Public Health. 2018;15:2373. doi: 10.3390/ ijerph15112373. 


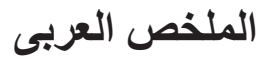

\title{
التغيرات النسيجية والكيميانسيجية التي يسببها الكاريزوبرودول (سومادريل) في قشرة

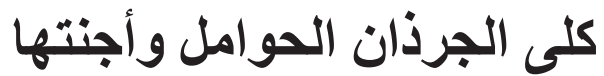

\author{
همت منصور عبد الحافظ ومرفت أحمد عبل ربه العابه

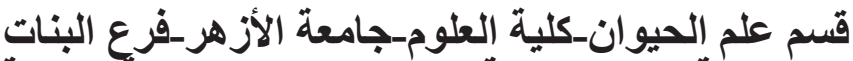

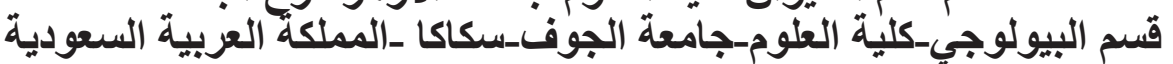

المقدمة: يعتبر عقار كاريزوبرودول من قائمة العقاقير التي تساعد على إرخاء العضلات، وهو أحد أنواع الأدوية المسكنة التي تعمل على تخفيف الشعور بالألم في مختلف الأماكن في الجسم فهو يقوم بإرخاء العضلات من خلال السيطرة على بعض الإشار ات أو حصر النبضات العصبية التي بتم إرسالها إلى المخ ويحدث تخفيف لأعر اض الثد العضلي والتشنجات التي تسبب الألم وبالتالي لا يشعر المريض بأي ألم. و إساءة استخدام الكاريزوبرودول وآثاره

الضارة على الصحة قد زاد بشكل كبير خلال السنوات القليلة الماضية بسبب آثاره المهيئة. الهدف من العمل: تهدف هذه الدر اسة إلى إيضاح التأثير الضار للجر عات العالية من عقار كاريزوبرودول على التركيب النسيجى و الكميانسيجى لنسيج قشرة الكلى للجرذان الحوامل وأجنتها. المواد والطرق: تم تقسيم الجرذان إلى ثلاث مجموعات (عشرة جرذان حوامل فى كل مجموعة). المجموعة الأولى استخدمت كمجموعة ضابطة، أما المجموعة الثانية والثالثة فتم إعطائهم جرعات فمية من عقار الكاريزوبرودول)

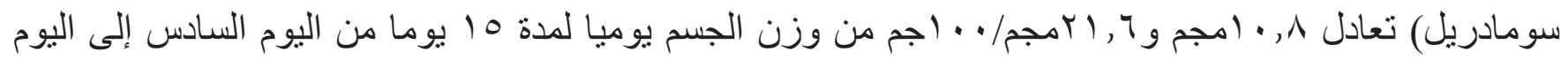
العشرين من الحمل. وأجريت در اسات نسيجية وكيميانسيجية على خلايا قثرة الكلى للأمهات وأجنتها. النتائج: وقد أوضحت النتائج ظهور تغير ات مرضية عديدة بنسيج قنرة الكلى للأمهات و الأجنة. وكانت التغير ات أكثر وضوحا فى نسيج قترة الكلى الجنيني لكلتا المجموعتين وتشمل هذه الأضرار ما يلي: إحتقان وتفصص وضمورفى الكبيبات البولية مع اتساع فى محفظة بومان، معظم الأنابيب فقدت شكلها الطبيعي حيث حدث تمدد فى الأنابيب البولية وضعف الكثف عن حدود تللك الأنابيب. وترسيب لحطام الخلايا وفقد اتصال الخلايا ببعضها وارتشاح لكريات الدم البيضاء داخل الأنيبيات، إستسقاء بين الأنابيب الكلوية، كما لوحظ أيضا تمدد فى الأو عية الدموية، بالإضافة إلى اتساع فى الأنابيب ونزف داخلى كما أدى استخدام عقار الكاريزوبرودول أيضا إلى زيادة كبيرة فى الألياف الكولا جينية في نسيج الكلى خصوصـا في الغشاء القاعدي للانابيب الملتوية.كما أظهرت المجموعات المعاملة بالكاريزوبرودول للأمهات و أجنتها انخفاضا ملحوظا في المو اد عديدة التسكر، المحتوى الكلى للبروتين وال DNA في قثرة الكلى وذلك مقارنة بالمجمو عة الضابطة، ولكن لوحظت زيادة و اضحة في بروتين الأميلويد في قثرة الكلى في المجمو عات المعاملة با الكاريزوبرودول مقارنة بالمجمو عة الضابطة. 
الخلاصة: إن استخدام عقار الكاريزوبرودول أثناء الحمل يؤدى إلى مخاطر و إلى تغيرات عديدة في نسيج الكلى للأمهات و الأجنة. 